\title{
Pawel SIWIEC
}

Jagiellonian University in Kraków

pawel.siwiec@uj.edu.pl

\section{STANDARD ARABIC - CORE VALUE OR VALUE ADDED?}

ABSTRACT In the opinion of the vast majority of the Arab society the literary Arabic is considered as a core value. Many even elevate it to the rank of sanctity, due to the fact that it is the language of the Koran. On the other hand Standard Arabic has never become a means of daily communication for all Arabs. It remains the language of written texts, ritual prayers and official speeches, while in everyday life people use dialects. Even Arabic language teachers in the Arab countries, when conducting classes in schools, speak a kind of intermediate Arabic or simply a dialect. In this context, the author tries to answer the question posed in the title of the present article.

Keywords: core value, standard Arabic, dialects, dyglossia, identity. 
W

hat inspired me to write this paper was a citation I came across while reading an article by Niloofar HAERI (2000: 61-87). It was the following piece of autobiography of prof. Leila Ahmed, a well-known Egyptian-American author specializing in the issues of Egyptian feminism:

The teacher called on me to read. I started haltingly. She began interrupting me, correcting me, quietly at first but gradually, as I stumbled on, with more and more irritation, leaving her desk now to stand over me and pounce on every mistake I made. She was an irascible woman, and I had not prepared my homework. "You're an Arab!" she finally screamed at me. "An Arab! And you don't know your own language!" "I'm not an Arab!" I said, suddenly furious myself. "I am Egyptian! And anyway we don't speak like this!" And I banged my book shut (HAeri 2000: 79).

The described situation took place in the middle of the past century, when Egypt, like the rest of the Arab world, was immersed in the ideology of pan-Arabism. As Haeri accurately remarks, it is a very compelling illustration of the problem of identity in the Arab society. And in this particular case it relates to the dilemma of being either Arab or Egyptian. In addition, it also demonstrates another fundamental issue for the Arabic language which is diglossia, i.e. a situation in which - according to the definition of C.A. Ferguson (1971: 16) -

in addition to the primary dialects of the language (which may include a standard or regional standards), there is a very divergent, highly codified (often grammatically more complex) superposed variety, the vehicle of a large and respected body of written literature, either of an Earlier period or in another speech community, which is learned largely by formal education and is used for most written and formal spoken purposes but is not used by any sector of the community for ordinary conversations. ${ }^{1}$

However, the scene presented above contains something more. The rebellious behavior of a teenage schoolgirl reveals the awareness of the unnatural linguistic dichotomy that she, like the rest of the Arab society, experiences. Because, for her, the mother tongue is not the imposed and detached from everyday life Standard Arabic, but the commonly used Egyptian dialect, that she learned at home from her parents.

In this context it should be mentioned that the Standard Arabic to a great extent owes its development and survival to Islam with which it is inextricably linked. As it is reiterated in the Koran, God revealed the Book in Arabic, which was the language of the prophet Muhammad and his tribe Qurayš:

An Arabic Koran have we sent it down, that ye might understand it (12:2).

For a comprehensive reviw on diglossia see: Hudson 2002: 1-48. 
Thus have We sent down to thee an Arabic Koran, and have set forth menaces therein diversely, that haply they may fear God, or that it may give birth to reflection in them (20:113).

It is thus moreover that we have revealed to thee an Arabic Koran, that thou mayest warn the mother city and all around it, and that thou mayest warn them of that day of the Gathering, of which there is no doubt when part shall be in Paradise and part in the flame (42:7).

We have made it an Arabic Koran that ye may understand (43:3) (THE KorAN).

Over the centuries, Muslim scholars have continually stressed the uniqueness and antiquity of the Arabic language. Twelfth century scholar Ibn cAsākir (1106-1175) in his opus vitae "The history of Damascus" (Tärīh madinat Dimašq) reports, citing Ibn Abbas, a cousin of the Prophet and the first Muslim exegete, that the language of Adam in paradise was Arabic (IBN ${ }^{\mathrm{C} A S A} \mathrm{~A} K I R$ 1995: 406-407). But when he disobeyed God, the Creator deprived him of Arabic and since then Adam spoke the Syrian language. Only when he expressed regret and repentance, God restored his ability to speak Arabic. The same story was quoted by a famous Islamic theologian and jurist Ğalāl ad-Dīn as-Suyūṭi (1445-1505) in his book "The Luminous Work Concerning the Sciences of Language and its Subfields" (Al-Muzhir fì culüm al-lugiga wa-anwāci-hā) (As-SuyūṬī 1986: 30).

According to the Muslim faith, the original copy of the Koran is in heaven where it was deposited on the so called Protected Tablet (al-lawh al-mahfüz), so that no impure forces could have access to it. ${ }^{2}$ In the opinion of some medieval exegetes, the Koran was written with light on a tablet made of red sapphire located at the throne of God and supported by the angel named Matiryun. Before its verses began to gradually descend to the Prophet Muhammad, God commanded angel Gabriel to place the Book in the lowest of the seven heavens called House of Power (Bayt al-cIzza) (AL-QURT U Bĩ 2006: 198-200).

Hence for Muslims, Koran is the purest holiness. Its text has no equal. It is unique and cannot be faithfully translated into any other language. That is why every Muslim (not just Arab), in order to make his everyday prayers ordered by the Supreme valid, must say them exclusively in Arabic. Thus, Koran in some measure has sanctified the Arabic tongue, whereas Islam has given it unprecedented growth, making it a literary language par excellence - the strongest medium of the rapidly expanding Arab-Muslim empire. The Koran, Islam and the Arabic language formed - as Nihād al-Mūsā put it - a triad of organically linked elements (AL-MŨSĀ 2007: 37), that completely subdued the territory stretching from the Atlantic coast of North Africa up to the western boundaries of the Central Kingdom. The elements of this triad became core values of the new culture that started emerging in the beginning of the $7^{\text {th }}$ century.

However, despite such a high rank to which the literary Arabic has been raised through the Koran, it has never become a means of daily communication for all Arabs. Even relatively early codification of its grammar in the second half of the $8^{\text {th }}$ cen-

As stated in the Koran: Yet it is a glorious Koran, Written on the preserved Table (85:21-22). 
tury, together with the dissemination of its teaching, could not help. Standard Arabic remained the language of written texts, ritual prayers and official speeches, while in everyday life people used dialects. And with the passage of time the dialects became more and more differentiated and at the same time increasingly distant from the standard written language. In the $13^{\text {th }}$ century, the famous Arab lexicographer Ibn Manzūir (1233-1311), in the preface to his monumental dictionary "The Arab tongue" (Lisan al-c Arab), warned that in his time the Arabic language had fallen into sloppiness and people competed with each other in showing off their eloquence in foreign languages. With a hint of sarcasm he compared his work to the ark that Noah built accompanied by jeers and laughter of his countrymen (IBN MANZŪR n.d.: 13). A hundred years later, the historian Ibn Haldūn (1332-1406) wrote that the Arabic of his contemporaries was no longer the language in which the Koran had been revealed. The reason behind that, according to him, was Arabs mixing with the conquered nations. He advised that in order to regain the ability of speaking Standard Arabic, people had to memorize as many texts as possible from the Koran, Sunna and old Arabic poetry (IBN Haldūn 2001: 771-772). Nevertheless, the advent of the $16^{\text {th }}$ century brought the Turkish rule that lasted almost 400 years pushing the Standard Arabic almost completely into the realm of religious rituals and sanctioning the eventual split between the literary and spoken Arabic.

The Arab cultural renaissance (an-nahda) at the turn of the $19^{\text {th }}$ and the $20^{\text {th }}$ centuries, initiated, after ages of stagnation, a battle for restoration and adaptation of the Arabic literary language, so that it could meet the challenges of the new times. In Egypt, modern- oriented intellectuals opted for creating an intermediate form of Arabic as a combination of the Standard and Spoken Arabic. Some more radical reformists proposed elevating the Egyptian dialect to the position of the literary language of modern Egypt. Many well-known personalities from the world of culture and politics supported these ideas. Among them was one of the most prominent Egyptian intellectuals Ahmad Luṭi as-Sayyid (1872-1963), a long-time director of the Arabic Language Academy in Egypt (ZAKKARIYĀ $\left.S_{A^{C} \bar{I} D} 1964: 123-149\right)$. In May 1943, a member of the Arabic Language Academy, ${ }^{c} A b d$ al- ${ }^{-}$Azīz Fahmī (1870-1951) suggested even replacing the Arabic script with Latin, following the Turkish example (ZAKKARIYĀ $S_{A}{ }^{c} \bar{I} D$ 1964: 144). The main arguments in favor of such profound and far-reaching reforms (except nationalistic political motivations) were: 1) saving Egyptian children hardship caused by the difference between the written and the spoken language, 2) elimination of the chasm between literature and the nation, 3) development of national literature, 4) and - what seems surprising - rapidly increasing interest of foreigners in learning Egyptian spoken Arabic (ZAKKARIYĀ SA ${ }^{\complement} \bar{I} \mathrm{D}$ 1964: 143).

These pursuits, however, were doomed to fail against strong opposition from the religious authorities and the conservative circles of the Muslim Al-Azhar University. Supporters of breaking with the Standard Arabic were exposed to massive criticism and often branded as enemies of the language of the Koran. Thus, the status quo binding for the past thirteen centuries was maintained and the problem of diglossia remained. 
The last quarter century, the era of internet and mobile phones, has provided new challenges. Especially the latter caused a real turbulence in the space of the Arabic language. When the first mobile phones appeared in the Arab markets they did not have Arabic keyboards. So, in order to be able to write text messages efficiently in Arabic, the phone users developed special Latin notation in which the letters denoting characteristic Arabic sounds have been substituted with digits similar in shape to the corresponding Arabic alphabet letters. Ipso facto, the appeal of ${ }^{\mathrm{c}} \mathrm{Abd}$ al- ${ }^{\mathrm{c}} \mathrm{Azìz}$ Fahmī to romanize the Arabic script has partly materialized. The language used in text messaging is colloquial Arabic interspersed with English or French words and phrases. The text messages are characterized by a shorthand style often saturated with foreign (mostly English) acronyms. The appearance of mobile phones with Arabic keyboards has not eliminated this phenomenon and the style quickly spread to internet instant messaging and chats rooms. Special name was even coined for this particular slang, namely Arabizi which is a combination of two Arabic words: 'arabì (Arabic) and ingilizzì (English). Over time, the term arabizi included also the macaronic jargon that has been used in everyday speech especially by young Arabs at least since the mid-eighties of the last century.

On the other hand, the Arabic internet forums are dominated by dialects or some kind of hybrid Arabic, in which the literary forms intermingle with dialectal ones. Interestingly, this also applies to the language of discussions concerning diglossia. To find that out, one only needs to google the following question in Arabic: لماذا لا نتكلم الفصحى (Why do we not speak the literary Arabic?) and then enter any listed forum website. What indeed has no precedent is the Egyptian Arabic Wikipedia (Wikipedia Masri). It was initiated in the end of 2008 and is available under the url $<$ https://arz.wikipedia.org > as a counterpart to the literary Arabic Wikipedia (<http://www.ar.wikipedia. org $>$ ) founded in the middle of 2003. Currently the Egyptian Arabic Wikipedia contains more than 16000 articles and is constantly evolving.

An attempt to revise the condition of the Arabic language in modern times has been made lately by Nihād AL-MŪSĀ (2007). In eleven chapters of his study he emphasizes a close relation of the Arabic literary language with Islam as well as with the cultural heritage and identity of Arabs. In this close relation he sees the strength and promise of survival. With regard to the problem of diglossia he points to the impact of the Turkish rule and the methodical francization of Maghreb in the late $19^{\text {th }}$ and early $20^{\text {th }}$ centuries. He speaks critically about the methodology of teaching literary Arabic on various levels of education in the Arab countries. He also points to the negative influence of the media $^{3}$ as well as the advertising and spread of education in foreign languages. Nihād al-Mūsā expresses his concerns about the process of globalization, which he identifies with Americanization. He asserts with bitterness that the usage of the literary Arabic by an average Arab resembles often broken English in mouths of non-native speakers (ALMūsĀ 2007: 70). He warns that the literary Arabic is losing prestige among its own users, which manifests itself, among others, in reluctance on the part of students and low rank of Arabic teachers compared with teachers of other subjects (AL-MŪsā 2007).

On diglossia in Arabic media see for example: Alshamrani 2012: 57-69. 
Nihād al-Mūsā, however, does not give answer to the question why the Arab society, especially its intellectual elite, has not solved the problem of diglossia so far and why the vast majority of educated Arabs still speak, at best, a sort of intermediate Arabic (al-carabiyya al-wustā ) which places sixth in his hierarchic list of thirteen varieties of Arabic being in use nowadays (AL-MūSĀ 2007: 20-21). The fact is that Nihād al-Mūsā does not even pose this question in his otherwise comprehensive work.

Case studies on Arab minorities in the West show that the Arabic language is considered by these communities as a fundamental value. However, the priority is always given to colloquial Arabic, a particular dialect which is considered as native language learned by children from the first moments of their life and naturally used every day. Literary Arabic is seen primarily through the prism of the Koran and Islam, or as an important element of education enabling full functioning in the Arab society. It is a rather difficult language, which one must laboriously learn in school like any foreign language and which is basically not used in everyday speech (GomaA 2011: 46-53; Alghazo 2007: 73-101). These studies also provide interesting insights on teaching Arabic to children and young people. Manal Alghazo in the conclusion of his article on factors affecting the maintenance of the Arabic language among Arab immigrants in the United States writes:

The curriculum taught at the school does not accommodate student's needs. It is abstract, linguistic based rather than being reflective of children's everyday lives. Although the school is lacking trained teachers and the use of good methodology and good curriculum it is still a factor in language maintenance for this group of Arab Americans, but not a very effective factor at this stage of the school's development.

The teachers should also have a positive effect on language maintenance, but in this study, the students showed lack of interest in their teachers, they didn't care much about them. Most of the children even felt that the teachers were not interested in teaching and didn't like teaching at all (Alghazo 2007: 96).

These observations entirely confirm the opinions of Nihād al-Mūsā. It is worth mentioning that even Arabic language teachers in the Arab countries, when conducting classes in schools, speak a kind of intermediate Arabic or simply a dialect. Examples of that can be found in numerous educational programs broadcast on Arab state TV channels, including programs aimed at dissemination of practical knowledge of the literary Arabic such as Yawmiyyat mudarrisa that is broadcast from Monday through Friday on Moroccan Arrabia TV, or the Moroccan Government-sponsored animated course for the illiterate, available on-line at <http://www.ealpha.alphamaroc.com>.

Maḥmūd Mụ̣ammad YūNIs 'ALİ (2004: 659-707), like presumably many other contemporary Arab scholars, considers that the Arabic language is currently in a crisis which is a consequence of what he calls "backwardness of the Arab mentality" (attahalluffì bunyat al-caql al-carabì). According to him, there are five main manifestations of such "backwardness" in the Arab society: dogmatism, emotional thinking, egocentrism, intellectual complacency and superficial thinking (YüNis 'ALİ 2004: 665). All of them translate into the poor condition of the Arabic language. M.M. Yünis 
'Alī picks to pieces educational programs and institutions responsible for Arabic language teaching, blaming them for indifference and shortsightedness. He also criticizes teachers for their incompetence and lack of commitment. But the most worrying for him is the separation of the literary Arabic from life, i.e. that it is not used in everyday conversations and is seen as if it were not a means of interpersonal communication. Consequently, it is taught as if it were a foreign language, though having much in common with the normally used local dialect.

Saudi columnist Māğid Bin Ğa ${ }^{c} f a r$ al-Gāmidī in his provocatively titled article "Identity and values - as exemplified by death of the Arabic language" (Al-Huwiyya wa-al-qiyam - mawt al-luga al-carabiyya namüdağan) (<http://www.saaid.net/ara$\mathrm{bic} / 355 . \mathrm{htm}>$ ) postulates abolishing of many practically not applied grammar rules as a remedy. Although he does not indicate what specific rules he has in mind, one can only assume that he means taking advantage of the "benefits" of a relatively large range of linguistic redundancy present in Standard Arabic. But this does not require any institutional intervention, because, as a specificity of the spoken literary Arabic, it falls within generally accepted linguistic correctness. Al-Gāmidī believes that such simplification could stop averting of young Arabs from the literary language, and subsequently encourage them to use it in daily verbal communication. Interestingly, Al-Gāmidī, with unconcealed respect, refers in this context to Eliezer Ben-Yehuda and the revival of the Hebrew language.

However, the problem of diglossia appears to be a much more complex and vital issue. In view of the latest neurolinguistic investigations diglossia can have a negative impact on cognitive processing in children. The reason is that it overtasks the working memory which plays an essential role in the development of the reading skills of persons who learn Standard Arabic. According to Raphiq IBRAHIm (2011: 571-582):

The diglossia and the gap in phonological distance (auditory-hearing) between dialects may play an important role in the processing of words from the literary language. The distance between the components is related to the existence of different phonemes in the spoken and literary language and to the differences in phonological structure of the syllables in the two languages word. This phonological distance between the two forms of the language can have a detrimental effect on the precision and speed of stimuli processing. [...] It can be assumed that the reduction in phonemic analysis ability, which is a basic ability in reading and writing, slows reading acquisition in the Arabic language early age. [...] Exposing children to this language before they enter school should help prevent immaturity in meta-lingual mechanisms in the standard literary language, reduce the gap between the spoken and the standard language, and ultimately make the process of reading acquisition easier. ${ }^{4}$

Therefore, solving the problem of diglossia is crucial not only because the future of Standard Arabic is at stake, but because it can negatively impact the linguistic development of children.

See also Ibrahim 2009: 93-105; Khamis DaKwar 2005: 75-86. 
There is unanimity in the Arab society that the problem of diglossia should be definitely and quickly overcome. Countless opinions and discussions on internet websites are sufficient evidence for this. But the fact is that the problem has not been solved yet and the prospects for the future do not seem encouraging. Therefore, although in the opinion of the vast majority of the Arab society the Standard Arabic is considered as a core value and by many even as sanctity, it appears to be rather a value added, i.e. something "extra" that goes beyond the standard expectations.

\section{REFERENCES:}

AlghAZo, Manal 2007: "Factors Influencing Arabic Language Maintenance In the United States," Journal of Faculty of Education UAEU 24: 73-101.

Al-QuRṬ UBī 2006: Al-Ğāmic li-ahkām al-Qur'ān. Vol. 22. Ed. by 'Abd Allāh Ibn 'Abd alMuhsin at-Turkī. Beirut: Mưassasat ar-Risāla.

Alshamrani, Hassan 2012: "Diglossia in Arabic TV Stations," Journal of King Saud University - Languages and Translation 24(1): 57-69. DOI: 10.1016/j.jksult.2011.04.002. As-SuYūṬ İ 1986: Al-Muzhir fì culūm al-luğa wa-anwāci-ha. Vol. 1. Beirut: Manšūrāt alMaktaba al-cAșriyya.

Ferguson, Charles A. 1971: Language Structure and Language Use. (Language Science and National Development.) Ed. by Anwar S. Dil. Stanford: Stanford University Press. GomaA, Yasser A. 2011: "Language Maintenance and Transmission: The Case of Egyptian Arabic in Durham, UK," International Journal of English Linguistics 1(1): 46-53. DOI: $10.5539 /$ ijel.v1n1p46.

HAERI, Niloofar 2000: "Form and Ideology: Arabic Sociolinguistics and Beyond," Annual Review of Anthropology 29: 61-87. DOI: 10.1146/annurev.anthro.29.1.61.

Hudson, Alan 2002: "Outline of a Theory of Diglossia," International Journal of the Sociology of Language 157: 1-48. DOI: 10.1515/ijsl.2002.039.

IBN 'AsĀKIR 1995: Tārīh madīnat Dimašq. Vol. 7. Beirut: Dār al-Fikr.

IBN HUALDŨN 2001: Dīwān al-mubtada' wa-al-habar fì tārīh al-c'Arab wa-al-Barbar waman 'āṣ̣ara-hum min dậ̄ aš-ša'n al-akbar. Vol. 1. Muqaddima. Beirut: Dār al-Fikr.

IBN MANZ ŪR n.d.: Lisān al-c'Arab. Cairo: Dār al-Macārif.

IBRAHim, Raphiq 2009: "The Cognitive Basis of Diglossia in Arabic: Evidence from a Repetition Priming Study within and between Languages," Psychology Research and Behavior Management 2: 93-105. DOI: 10.2147/PRBM.S5138.

IвRAнiм, Raphiq 2011: "Literacy Problems in Arabic: Sensitivity to Diglossia in Tasks Involving Working Memory," Journal of Neurolinguistics 24(5): 571-582. DOI: 10.1016/j.jneuroling.2010.10.003.

Khamis Dakwar, Reem 2005: "Children's Attitudes Towards the Diglossic Situation in Arabic and its Impact on Learning," Languages, Communities, and Education 2: 7586.

The Koran: The Koran 1909. (Everyman's Library. Philosophy \& Theology. 380.) Transl. by J.M. Rodwell. London/New York: J.M. Dent/E.P. Dutton. 
AL-Mūsā, Nihād 2007: Al-lugia al-carabiyya fì al-cașr al-ḥadịt, qiyam aț-țubūt wa-quwā at-tahawwul. Amman: Dār aš-Šurūq

YŨNIS 'ALī, Maḥmūd Muhammad 2004: "Azmat al-lug̉a wa-muškilat at-taḩalluf fĩ bunyat al-caql al-carabī al-mucāșir," Mağallat Ğāmicat Umm al-Qurā li-cUlūm aš-Šarī'ca waal-Luġa al-cArabiyya wa-Ādābi-hā 17/29: 659-707.

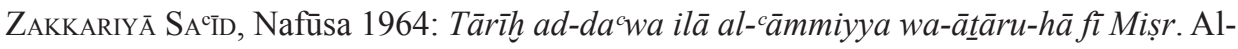
exandria: Dār Našr aț-Taqāafa.

$<$ http://www.saaid.net/arabic/355.htm>.

Paweł SIWIEC, Ph.D., Associate Professor at the Jagiellonian University, Kraków (Faculty of International and Political Studies, Institute of the Middle and Far East). Main fields of research: Arabic poetics, classical and contemporary Arabic language, Arabic dialectology. 